\title{
Youth Employment and Unemployment in the Digital Economy Epoch
}

\author{
Tyutyunnikova Svetlana V. ${ }^{1}$, Romanika Tetiana K. ${ }^{2}$ \\ ${ }^{I}$ Doctor of Economics, Professor of the Economic Theory and Economic Management Methods \\ Department at the Faculty of Economics, V. N. Karazin Kharkiv National University, Ukraine \\ ${ }^{2}$ Ph D student of the Economic Theory and Economic Management Methods Department at the School of \\ Economics, V. N. Karazin Kharkiv National University, Ukraine
}

\begin{abstract}
The digital economy, as a result of the fourth industrial revolution, is gradually becoming the leading direction of modern development. Unlike other technologies, digital and cognitive ones tend to penetrate into any technical processes. Digitalization is becoming an integral technological platform capable of uniting all subjects of the market area into a single economic mechanism. The rapid development of technology requires a comprehensive study of this process influence on the economic and social life of society, especially the young generation. Analyzing the problems of youth employment and unemployment, one can see the consequences of the digital economy such as changes in the content and organization of work, structural changes of the active population for the employed and employed, dynamic changes within the category of employees according to professional, sexual, regional, national and gender aspects. The ambiguous and sometimes contradictory impact of the digital economy on youth employment determines the methodological interrelationship of the latest technologies and the sphere of social and labour relations. The combination of scientific, technical and humanitarian knowledge makes it possible, firstly, to develop practical recommendations for the economic life of society based on the nature-like technologies, and, secondly, to formulate a system of human capital competencies. The significant negative consequences of digitization of the economy is unstable and youth unemployment. Neutralizing the negative impact of the digital economy is the basis of creating an inclusive environment, developing national programs to support youth employment, and standardizing rules on employment regulation.
\end{abstract}

Keywords: competence, distance employment, inclusive mode, Internet platform, precarious employment 


\section{Introduction}

The employment of the population, especially of its youth segment, is becoming an acute problem which is due to the digital economy, its potential capacity and its losses. Based on global information and communication networks that unite all participants (producers, consumers, partners, clients, young people and adults) into a single economic mechanism, the digital economy has a significant impact on youth employment. Being the result of the fourth industrial revolution, the digital economy provides national competitiveness and security, creates unique opportunities for the development of human capital, stimulates innovation and creative industries. Ukraine is making efforts to be engaged in these revolutionary technological transformations with all possible consequences. Having joined the Declaration of the first meeting of the Ministers of the «Eastern Partnership» on the digital economy in June 2015, Ukraine has consolidated its intention to cooperate with the EU and its neighbours in this field.

Digitization of the economy significantly affects employment, motivation, introduces special requirements to the competences of human capital. Transformation processes in the field of employment are associated with changes in the content and job characteristics, leading to the dynamic shift in the age structure of employment system.

The significance of the methodological issues studying of the connection between the digital economy formation and employment is not in doubt. The effects of transformational changes in employment require both theoretical reflection and the development of concrete measures to increase youth employment.

Modern information and telecommunication technologies, with their rapidly growing potential and decreasing costs, provide great opportunities for new forms of work and employment organization within the framework of both individual corporations and society as a whole. The scope of these opportunities is greatly expanding as these innovations affect all spheres of people's life such as families, education, labour, geographical boundaries of human communities and so on.

Nowadays, information technologies contribute greatly to the strengthening of the interrelation between the labour productivity growth, output, investment and employment. New types of services distributed in the network are able to create a lot of jobs, which is confirmed by the practice of recent years.

The purpose of this study is to identify the impact of the digital economy on youth employment, to identify the main features of youth employment changes, to trace the transformation of the content of labor and flexible forms of employment in the process of the economy digitalization.

\section{Body of paper}

The «digital tsunami» destroys the current notion of employment. Most of jobs we know today will be outdated and replaced by the latest generation of robotics: printing of 3D objects, document translation, insurance policies, elderly homecare, medical consultations, each of which is more important than the other. The very concept of «work» may become obsolete and be replaced by a constantly changing algorithm of projects designed to operate through Internet platforms. 
The effects of digitalization can range from massive changes in the number and sectoral workplaces to radical redirection of work organized at the workplace. We mean new digital platforms that allow not only to reconcile service providers and customers through a highly effective mediator in the labour market, but also to manage economic activity.

J. Scott Brennan and Daniel Cruis define digitalization: «as the way in which many domains of social life are restructured around digital communication and media infrastructures» (Brennen and Kreiss, 2016). They base their definition of digitalization on structural shifts and change the relationships between people.

Gartner claims that «digitization is the use of digital technologies to change the business model and provide new opportunities for gaining income and value. This is the process of transition to digital business» (Gartner, 2019). Thus definition focuses on business model changing rather than on social interactions.

The latest report by the Brookings Institution, Digitalization and American Workforce, cites: «Digitization is the process of using digital technologies and information to transform business processes». The Brookings report focuses on how digitalization affects people. «Digitalization transforms the world of work», the report says. «The acquisition of digital skills has become a prerequisite for the success of the individual, industry and the region» (Muro, Liu, Whiton and Kulkarni, 2017).

The rapid technological development of digital data processing provides technological opportunities letting the forms of employment which used to be non-typical to grow fast. The digital economy, of course, creates new jobs, expands opportunities for the youth. Young people are dynamic and mobile; they are not «locked» by traditional employment requirements. They are able to combine at the same time a lot of duties, social roles with rest and leisure. But digital economy does not solve the problem of youth unemployment. Course, no. Because, firstly, digitalization means optimization, and reduction of job growth; Secondly, digitalization is accompanied by an increase in unstable employment, temporary and incomplete; thirdly, certain types of employment are traditionally assigned to more experienced workers, where competitive advantages are not always for young people.

It's also important to pay attention to the necessity for new forms of employment to find synthesis, synergy of wisdom and youth, reconciliation of opposites (the removal of tension between labor and capital), harmony between a man and nature through sustainable civilized development.

The digitalization of the economy affects sufficiently not only the content of labour, but also employment, especially of youth.

Different authors such as Eva Buntmann-Masum (France), Adam Fish (Great Britain), Olivier Freise (Sorbonne, France), Vincent Moskow (Canada) trying to identify the unique aspects of work in the digital economy used the concept of virtual work, a general term which is used to identify all types of work carried out both at home and in public places or in a traditional working environment using the Internet, computers or other information-based tools. The spread of these new (or quasi-new) forms of work was accompanied by new forms of employment that combine non-traditional jobs, technology use and new contractual mechanisms.

Researchers of the European Fund have identified the following most common forms of employment (Eurofound, 2015):

- Distribution of employees, where a single employee is collectively hired by a group of employers and works in different companies on a rotational basis; 
- labour sharing, when a single employer employs two or more employees to perform one rotational shift work within one company;

- Temporary employment, when the employer temporarily hires a highly skilled specialist to carry out a specific project;

- day-to-day work, when an employment contract allows employees to be called hired on a flexible basis, and specific hours of work are not defined;

- ICT (ICT) work is the mobile work where employees do not use the employer's premises;

- work based on vouchers, where the working relationship involves paying for services with a voucher purchased from a third party (usually a public body), which includes both salary and social security payments;

- portfolio work, where a self-employed person performs a small job for a large number of clients;

- crowdsourcing, when an online platform brings employers to employees where projects are often divided into micro-tasks and are shared between the «virtual» team of workers;

- Joint self-employment that is observed in a number of countries, where more flexible forms of cooperation (such as common working spaces) are used to avoid restrictions on traditional business partnerships.

According to a survey of more than 32,000 people in 14 EU Member States conducted by the Joint Research Center, one in every 10 adults (aged 16-74) in several EU countries used online platforms at least once to provide labour services. Although for the majority it remains only a sporadic source of additional income, $2 \%$ of adults work more than 20 hours a week or earn at least half of their income via an online platform (European Commission, 2018).

The results of the study provided an opportunity to outline the main features of platform employees, learn about their working conditions and motivation, and also describe the type of services provided via the Internet platform.

The ambiguous relationship between companies and employees who occupy position somewhere between paid work and self-employment, is governed by a series of measures that have emerged in recent years as well as the latest transformations that have triggered the popularization of the digital economy, spread the tendency to use wage outsourcing for self-employed workers for using different platforms. This tendency can be observed in an ever-expanding range of industries including not only design, information technology, writing, transport, tourism and many tasks generated by the Internet as well as «real» tasks such as child care, dog walking and so on.

The occupations of such workers vary from highly skilled IT and creative professionals to unskilled amateurs, but most of them are young people looking for extra incomes, students, unemployed or guardians. Few of them consider it as their main job.

The consequences of crowdsourcing in terms of working conditions as a rule are negative (Green, de Hoyos, Barnes, Baldauf and Behle, 2013). With regard to the benefits, crowdsourcing offers a high degree of flexibility and autonomy, increased personal efficiency, ICT skills and a better balance between work and personal life.

Considering the labour market more globally, you can see that this form of employment offers a lot of opportunities (in particular for creative workers) and has great potential in terms of income, mobility and accessibility for those who have the least access to traditional forms of employment as well as jobs that this form of labour creates. 
Despite the fact that specialized platforms for crowdsources are obliged to adhere to the general legal provisions in the form of commercial law, consumer protection directives, the civil code and data protection norms, specific legislation on crowdsourcing has not yet been defined. Employees are actually self-employed, and the general conditions of the platforms define all the details (for example, remuneration, labour conditions and intellectual property). Such observations have led some authors to using terms such as «cybertariat» (Huws, 2009) or «force de la multitude» (Colin and Verdier, 2012) to highlight this form of employment as a unique one for the digital economy. In the digital economy «cybertariat» is a specific social layer of workers characterized by work sharing out of the territory, the weakening of social ties both between the workers, and the worker and the employer, so there is a risk of reducing the bargaining power of employees because of their territorial branching, which may lead to a reduction in wages. The «power of most people» plays an important role in value creating. In fact, the mass of educated, creative, experienced and interrelated individuals is a tremendous wealth that violates traditional practices.

There is a number of different contract models headed by the most famous one called the «zerohours contract». It is used in the United Kingdom, Ireland and the Netherlands, and provides a contract agreement without a guaranteed amount of work. In Ireland, however, the compensation must be paid if the amount of work hours reduces to a quarter. In other countries, minimum working hours (usually between a quarter and a third) are used without any guarantee of work. In other cases, for example, under min-max contracts applicable in the Netherlands, legislation sets limit for working hours, so part-time employment may be introduced in response to fluctuations in production volumes (Pfeiffer, 2013).

New forms of work in the digital economy are characterized by blurred borders at several levels, each of which concerns the issue of staff regulation:

- the problem of «work-personal life» balancing is not new but it has new meaning due to the increasing popularity of virtual work.

- the lack of a clear distinction between the status of employed and self-employed workers is particularly relevant especially for those working in the creative and journalism sector.

At the present time the Ukrainians have access to the digital labour market via a variety of platforms such as international, regional and local ones. The most popular platforms for the Ukrainians are the following: Freelancehunt.com, Kabanchik.ua, Freelance.ua, Upwork.com, Freelance.ru, Freelancer.com. As of March 2018, at least half a million registered workers from Ukraine worked on 6 platforms. This represents approximately $3 \%$ of the employed population (estimated at 16.2 million in January 2016). Although on some platforms, only about a quarter of these workers are active, and some workers are registered on several platforms. It is still only the tip of the iceberg. The fact that this phenomenon practically did not exist ten years ago confirms its high potential (Aleksynska, Bastrakova, Kharchenko, 2018).

In early 2018, Ukraine ratified all fundamental and priority ILO conventions, as well as 59 of 177 technical conventions. Many of these international labour standards are reflected in the labour legislation of Ukraine.

Employees of Internet platforms are located in each region of Ukraine. In a quantitative study, the proportion of men and women among workers in the platforms is approximately the same, respectively $52 \%$ and $48 \%$ (Figure 1). Although both sexes are equally represented in the age group of 26-30 years, there are insignificant gender differences among younger and older groups. Among young people (18- 


\section{$9^{\text {th }}$ INTERNATIONAL CONFERENCE ON MANAGEMENT , ECONOMICS AND HUMANITIES \\ 26-28 July, 2019

25 years), women are significantly more than men; in the older group $41+$ the situation has changed. In general, young people predominate in online work in Ukraine: two thirds of workers under the age of 36 . The average age of a platform employee is 33 years old.

Figure 1. Distribution of online work platforms according to the gender and age

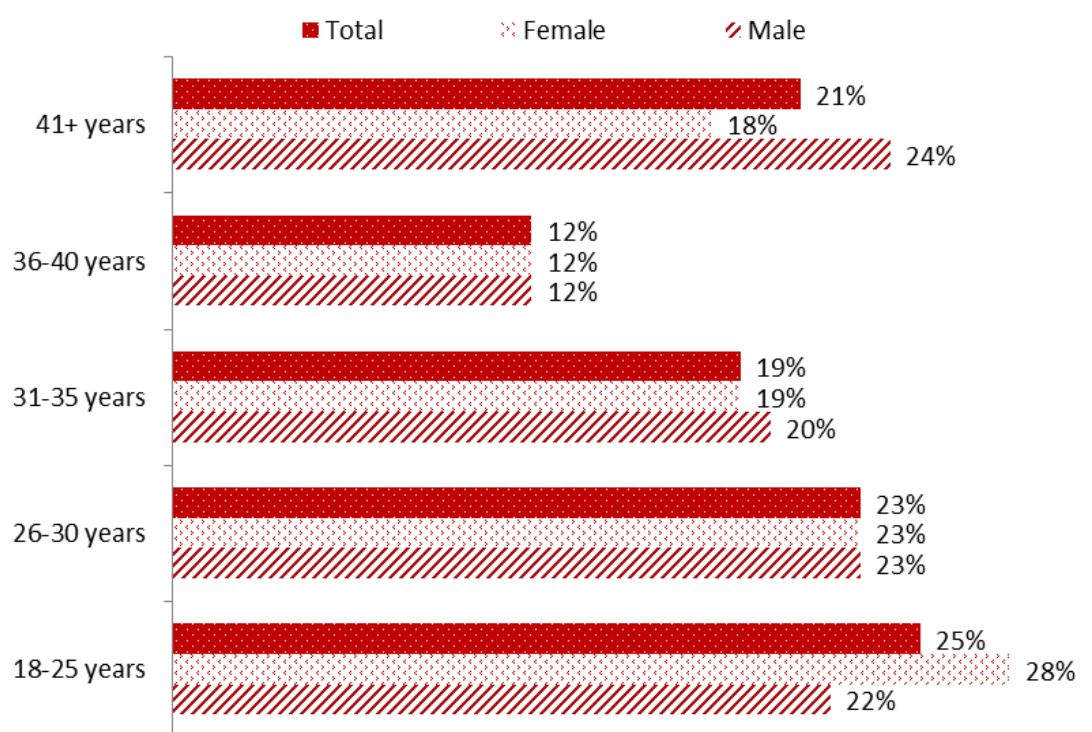

Source: (Aleksynska, Bastrakova, Kharchenko, 2018)

Ukrainian workers are highly educated. The majority (73\%) has a basic undergraduate degree or a full-time higher education. 2\% have a PhD degree (Figure 2). A quarter of respondents (25\%) continue their studies at present, with half of them (48\%) studying outside the formal education system through various training and specialized courses. In addition to formal diplomas, knowledge of foreign languages is essential to get an access to work on the Internet, for certain types of tasks and for choosing a platform. More than $18 \%$ of respondents claim that they speak English at the highest proficient $\mathrm{C} 1-\mathrm{C} 2$ level according to CEFR standard (although only 2\% actually do), while other $41 \%$ say that their English is intermediate (B1 level).

Figure 2. Distribution of online platform employees according to the level of education 


\section{$9^{\text {th }}$ INTERNATIONAL CONFERENCE ON MANAGEMENT , ECONOMICS AND HUMANITIES}

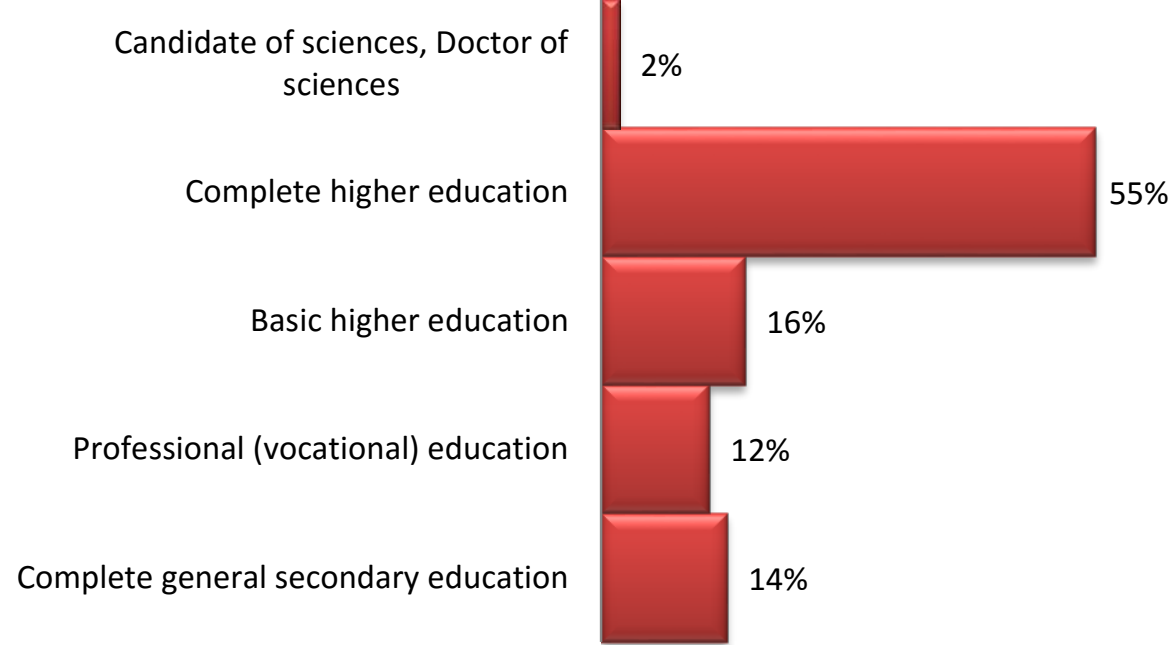

Source: (Aleksynska, Bastrakova, Kharchenko, 2018)

Digitization of the economy makes it difficult to determine the boundaries between dependent employment and self-employment. For example, in Germany the White Paper «Work 4.0» published by the Minister of Labour and Social Affairs contains a number of suggestions and proposals on labour conditions and the provision of adequate financial and social protection in this context. These proposals include the providing of pensions to all self-employed groups, the definition of the difference between dependent employment and occupation (Eurofound, 2017).

The European Social Insurance Platform which represents national social security organizations recently conducted a survey on compulsory retirement insurance for digital platform workers (ESIP, 2017), in particular virtual service providers (design, graphics, web page development, software development), translation etc.

In countries such as Austria, Belgium, Finland, Germany, Luxembourg, the Netherlands, Norway, Poland and Norway job performers are primarily self-employed. Nearly half of the countries require mandatory inclusion in the pension program although voluntary access is available in some countries. However, retirement benefits as a rule are subject to income received. The rates of contributions often vary according to the category of employee.

The position of the European Parliament, in general terms, is that fair working conditions and adequate legal and social protection should be ensured for all workers in the sharing economy, regardless of their status.

\section{Conclusion}

The digital economy has a significant effect on all aspects of economic activity of people, it plays a special role in youth employment. This influence is controversial: on the one hand, it 


\section{$9^{\text {th }}$ INTERNATIONAL CONFERENCE ON}

MANAGEMENT , ECONOMICS AND HUMANITIES

expands the opportunities for youth employment growth, and on the other hand, digitalization leads to a reduction in employment.

Young people as the most dynamic and mobile segment of the employed population are the most adaptable one to new working conditions and requirements of new business development patterns.

The digital economy pace of growth and the tendency of its impact on youth employment have major national and geographical differences. It concerns both the structural features of employment and its forms.

Many aspects of flexible employment, the growth of which is due to the development of the digital economy, entails not only the benefits to the employed, but the risks as well. Changes in social-labour relations system and social protection of the employed require institutionalization.

The growth of the digital economy will be accompanied by radical changes in the content of work and employment. New technologies require new and profound knowledge, both natural and humanitarian. The educational system needs to be reconstructed so that young professionals get the full range of contradictory complementary perspectives.

\section{References}

[1] Brennen, J. S. and Kreiss, D. (2016). Digitalization. In The International Encyclopedia of Communication Theory and Philosophy [online] Available: https://onlinelibrary.wiley.com/doi/full/10.1002/9781118766804.wbiect111

[2] Gartner IT Glossary. (2019). Digitization - Gartner IT Glossary. [online] Available: https://www.gartner.com/it-glossary/digitization/

[3] Mark Muro, Sifan Liu, Jacob Whiton and Siddharth Kulkarni (2017). Digitalisation and American Workforce. [online] Brookings.edu [online] Available: https://www.brookings.edu/wpcontent/uploads/2017/11/mpp_2017nov15_digitalization_full_report.pdf\#page=27

[4] Eurofound (2015), New forms of employment, Publications Office of the European Union, Luxembourg [online]

Available: https://www.eurofound.europa.eu/sites/default/files/ef_publication/field_ef_document/ef146 1 en.pdf

[5] European Commission (2018). Digital employment platforms gaining a foothold in Europe's labour markets [online] Available: https://ec.europa.eu/jrc/en/news/digital-employmentplatforms-in-europe

[6] Green A., de Hoyos M., Barnes S-A., Baldauf B. and Behle H. (2013) CrowdEmploy: crowdsourcing case studies. An empirical investigation into the impact of crowdsourcing on employability, European Commission Joint Research Centre, Institute for Prospective Technological Studies, JRC Technical Reports, EUR 26351, Luxembourg, Publications Office of the European Union [online] Available: http://publications.jrc.ec.europa.eu/repository/bitstream/JRC85751//fna26351enn.pdf

[7] Huws, U. (2009). The Making of a Cybertariat: Virtual Work in a Real World [online] Available: https://socialistregister.com/index.php/srv/article/view/5753/2649 
[8] L'Age de la multitude. Entreprendre et gouverner après la révolution numérique, de Nicolas Colin et Henri Verdier. Armand Colin, 285 pages.

[9] Sabine Pfeiffer. Work Organisation, Labour \& Globalisation. Vol. 7, No. 1 (Summer 2013), pp. 12-30.

[10] Mariya Aleksynska, Anastasia Bastrakova, Natalia Kharchenko (2018). Work on Digital Labour Platforms in Ukraine: Issues and Policy Perspectives. ILO, 2018. ISBN: 978-92-2030735-9 (web pdf) [online] Available: https://www.ilo.org/wcmsp5/groups/public/--ed_protect/---protrav/---travail/documents/publication/wcms_635370.pdf

[11] Eurofound (2017). Work-life balance and flexible working arrangements in the European Union [online] Available: https://www.eurofound.europa.eu/publications/customisedreport/2017/work-life-balance-and-flexible-working-arrangements-in-the-european-union

[12] ESIP (2017). Statutory pension coverage of platform workers - a comparative perspective, ESIP [online] Available: https://www.esip.eu/images/pdf_docs/Mapping---Statutorypension-coverage-of-platform-workers.pdf 